\title{
Isolation of oxidase-negative Aeromonas salmonicida from diseased turbot Scophthalmus maximus
}

\author{
Karl Pedersen ${ }^{1}$, Hans Kofod ${ }^{1}$, Inger Dalsgaard ${ }^{2}$, Jens Laurits Larsen ${ }^{1}$ \\ ${ }^{1}$ Royal Veterinary and Agricultural University, Section of Fish Diseases, 13 Bülowsvej, DK-1870 Frederiksberg C, Denmark \\ ${ }^{2}$ Danish Institute for Fisheries and Marine Research, Laboratory of Fish Diseases, 13 Bülowsvej, DK-1870 Frederiksberg C, Denmark
}

\begin{abstract}
The first outbreak of disease due to an atypical Aeromonas salmonicida among turbot Scophthalmus maximus (L.) in Denmark is reported. The causal organism was oxidase-negative, non-pigmented, and slow-growing. Additionally it differed from the typical strains in a number of biochemical characters. The mortality among turbot in the farm was high but was responsive to antimicrobial therapy.
\end{abstract}

KEY WORDS: Atypical - Aeromonas salmonicida - Turbot Ulcerative lesions

Aeromonas salmonicida is the causative agent of furunculosis, a disease generally restricted to salmonids in fresh water (Austin \& Austin 1987). However, an increasing number of atypical $A$. salmonicida have been isolated from diseased fish from various parts of the world. These strains have been isolated from freshwater fish as well as marine fish and are not restricted to salmonids. Atypical A. salmonicida have been reported to have caused ulcerative lesions or other clinical signs in carp Cyprinus carpio (McCarthy 1977), minnow Phoxinus phoxinus (Håstein et al. 1978), Atlantic salmon Salmo salar (Paterson et al. 1980), goldfish Carassius auratus (Elliott \& Shotts 1980. Whittington et al. 1987), Atlantic cod Gadus morhua (Cornick et al. 1984), eel Anguilla anguilla (Kitao et al. 1985), sand-eels Ammodytes lancea and Hyperoplus lanceolatus (Dalsgaard \& Paulsen 1986), pike Esox lucius (Wiklund 1990), and flounder Platichthys flesus (Wiklund \& Bylund 1991)

Atypical Aeromonas salmonicida strains may differ in various characters such as fermentation of carbohydrates (McCarthy 1977. Wiklund 1990), amino acid decarboxylation (McCarthy 1977), oxidase reaction (Wiklund \& Bylund 1991), growth intensity and requirements for growth factors (McCarthy 1977, Ishiguro et al. 1986). Chapman et al. (1991) reparted the isolation of oxidase-negative but otherwise typical A. salmonicida.

This paper describes the outbreak of an ulcerative disease caused by an atypical Aeromonas salmonicida strain among turbot in a Danish salt water fish farm.

Materials and methods. Turbot: The main production on the farm was rainbow trout Oncorhynchus mykiss. Turbot production occurred on the facility on an experimental basis. The number of turbot before the outbreak of disease was approximately 3200 , distributed in twelve $1000 \mathrm{I}$ tanks, and with an average body weight of approximately $100 \mathrm{~g}$.

Bacteriological and serological examination: Initial cultures were made on marine agar (Difco, Detroit, MI, USA) supplemented with $5 \%$ calf blood (BA) and incubated at $20^{\circ} \mathrm{C}$ for $4 \mathrm{~d}$. Bacteria were identified according to Popoff (1984) using methods outlined by Cowan (1974). Vibrio anguillarum strains were serotyped as described by Sorensen \& Larsen (1986), while serological examination of Aeromonas was performed as described by Dalsgaard \& Paulsen (1986).

Protein staining: The reaction of Aeromonas colonies with Coomassie blue and Congo red was examined as described by Evenberg et al. (1985) and Ishiguro et al. (1985), respectively,

SDS-PAGE and western blotting: Protein samples were prepared from stationary phase broth cultures. Cultures were transferred to Eppendorf microfuge tubes and centrifuged at $8000 \mathrm{rpm}$ for $10 \mathrm{~min}$. Pellets were washed in phosphate buffered saline (PBS), $\mathrm{pH}$ 7.3 , resuspended in $20 \mu \mathrm{l}$ distilled water, and $300 \mu \mathrm{l}$ sample buffer $[0.0625 \mathrm{M}$ Tris (pH 6.8), $5 \%$ mercaptoethanol, $10 \%$ glycerol, and $2 \%$ SDS] was then added. The mixtures were boiled for 5 min, diluted with $320 \mu \mathrm{l}$ of distilled water, boiled again for $5 \mathrm{~min}$, and centri- 
fuged at $13000 \mathrm{rpm}$ for $5 \mathrm{~min}$. Three hundred $\mathrm{ml}$ of supernatant were transferred to new microfuge tubes and $40 \mu \mathrm{l}$ of sample buffer containing $0.0001 \%$ bromophenol blue was then added. Purified protein A from A. salmonicida subsp. salmonicida was obtained as a kind gift from Dr L. J. Reitan, Veterinæerinstituttet, Oslo, Norway. Bacterial protein preparations and purified protein A were subjected to SDS-PAGE (Laemmli 1970) and blotted onto nitrocellulose membrane (western blotting). Blocking and subsequent incubations were carried out at room temperature in a blocking buffer consisting of PBS containing $1.0 \%$ non-fat instant dry milk. The nitrocellulose membranes were incubated with serum from infected and uninfected turbot followed by rabbit anti-turbot antiserum (Kofod et aì. 1994), and peroxidase iabeled swine anti-rabbit IgG (Dako, Glostrup, Denmark). Between steps, membranes were washed 4 times in PBS containing $0.05 \%$ Twcen 80. Peroxidase activity was detected with $10 \mathrm{mg}$ diaminobenzidine (DAB; Sigma, St. Louis, $\mathrm{MO}$, USA) dissolved in $40 \mathrm{ml} \mathrm{H}_{2} \mathrm{O}$ containing $20 \mu \mathrm{l} 30 \%$ $\mathrm{H}_{2} \mathrm{O}_{2}$.

Antibiotic sensitivity: Antibiotic sensitivity testing was carried out on BA using the agar diffusion method (Neo-Sensitabs, Rosco, Denmark).
Pathogenicity test: In order to determine an $\mathrm{LD}_{50}$ value (Reed \& Muench 1938) for the strain in salmonids, groups of 6 Atlantic salmon Salmo salar (L.) were injected with approximately, $1.3 \times 10^{8}, 1.3 \times 10^{6}$, $1.3 \times 10^{4}$, or $1.3 \times 10^{2}$ colony-forming units (CFU) in PBS or with PBS alone as control. Bacteria for the challenge were obtained from a broth culture by centrifugation; they were then resuspended in PBS. Each group of fish was kept in a separate tank at $16^{\circ} \mathrm{C}$

Results and discussion. In mid June most of the turbot developed a disease with lethargy and skin lesions as the predominant signs. The lesions usually started as erosions at the tip of the skin nodules, with a white center surrounded by a thin hemorrhagic zone (Fig. 1) approximately ' 2 to $4 \mathrm{~mm}$ in diameter. It is uncertain whether the erosions were part of the infection or whether they were caused by mechanical or other damage and subsequently formed the port of entry for the pathogen. Some erosions developed into ulcers that varied in size from approximately 0.5 to $3 \mathrm{~cm}$ in diameter and were distributed over the whole body, the dorsal and the ventral surfaces being equally affected (Fig. 2). Typical ulcers had an umbonate appearence with a hemorrhagic center surrounded by a

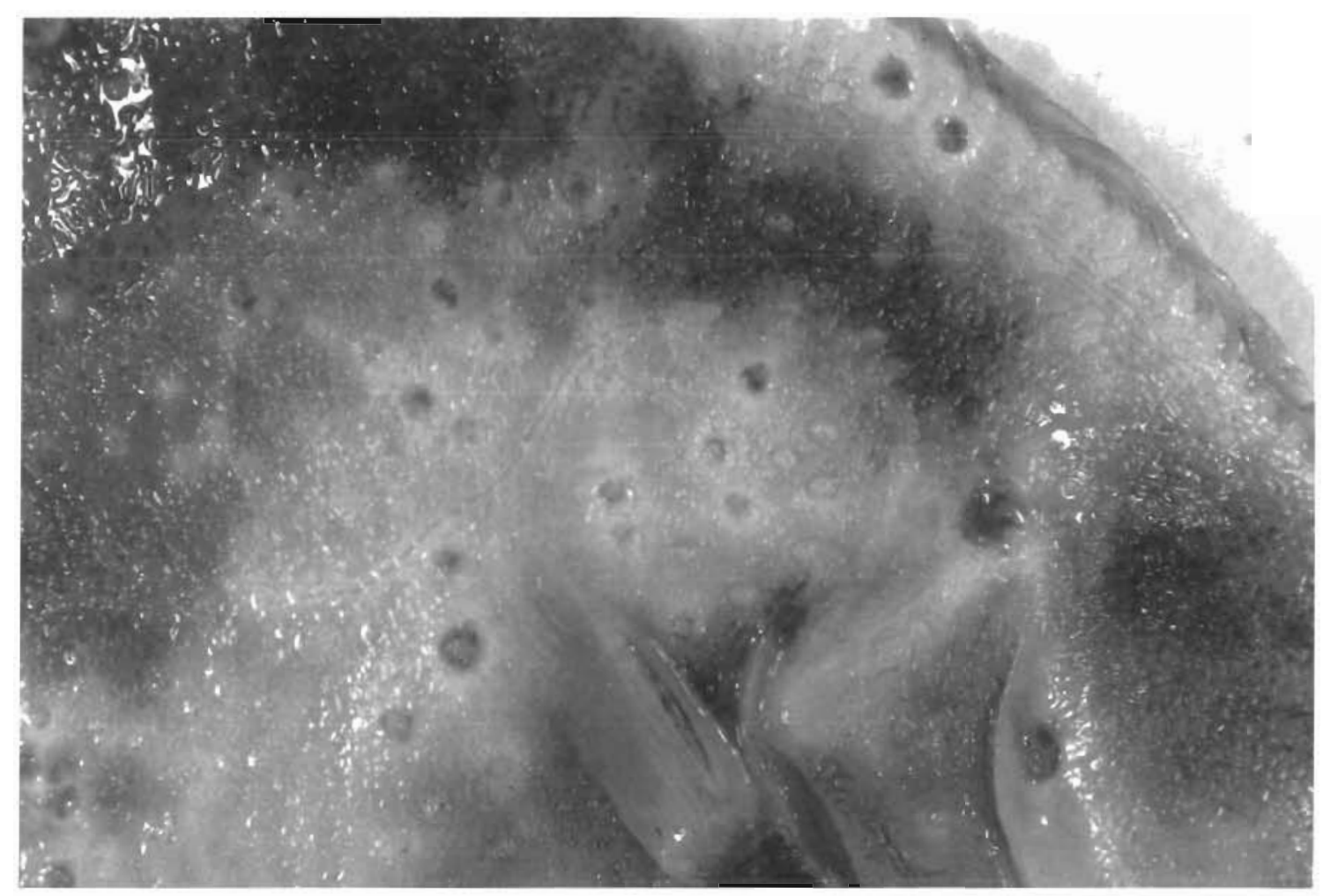

Fig. 1. Scophthalmus inaximus. Small erosions and ulcers, 2 to $4 \mathrm{~mm}$ in diameter, at the tip of the skin nodules of a turbot. These erosions may have been caused by mechanical damage and may have been the port of entry of the Aeromonas strain. A small ulcer is recognized at the operculum. On several fish large, irregular ulcers were detected here as well as on various sites on the head or at the base of the fins 


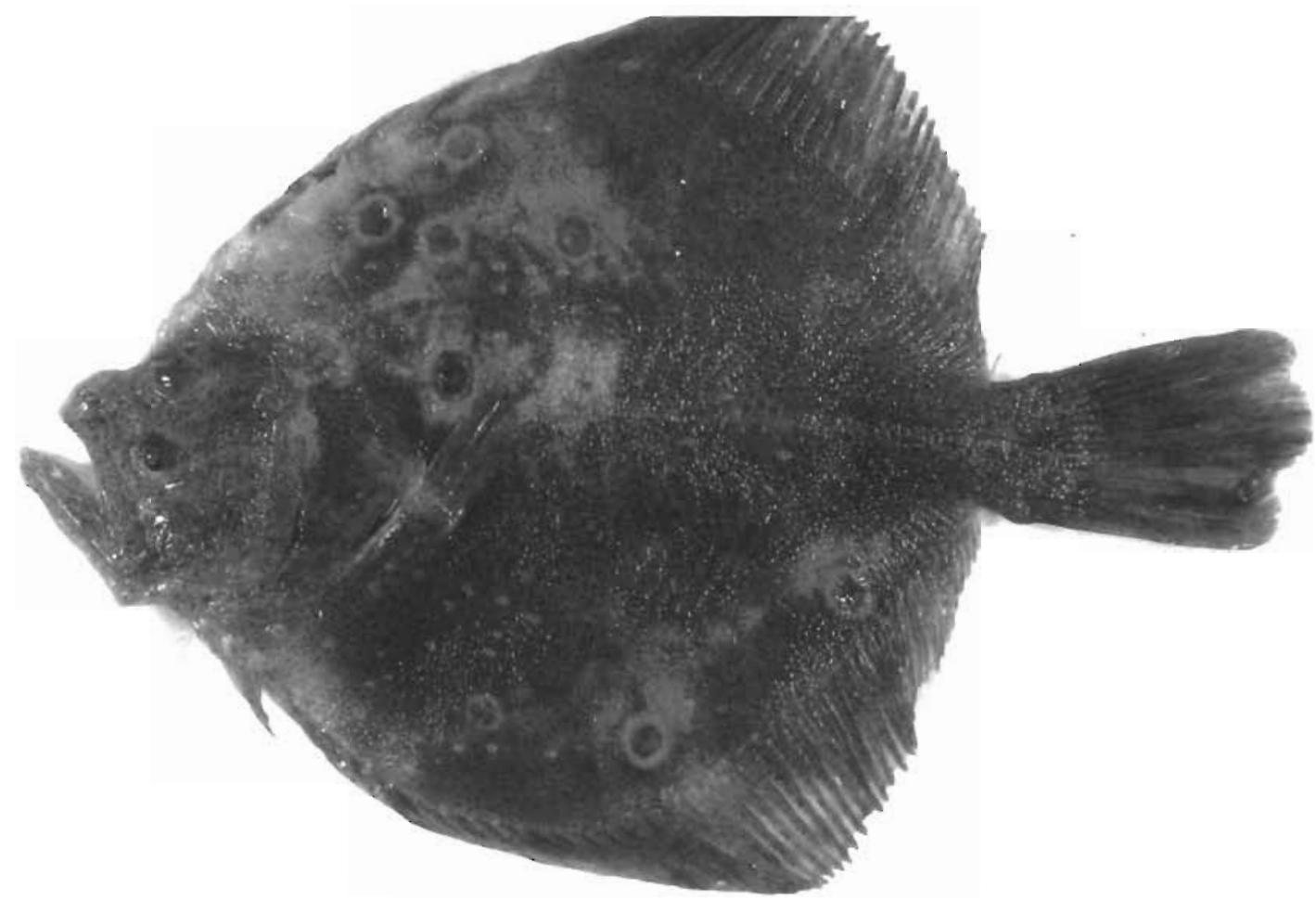

Fig. 2. Scophthalmus maximus. Typical ulcers on the dorsal, pigmented side of the turbot. Ulcers, approximately $0.5-3 \mathrm{~cm}$ in diameter, were found and were equally frequent on dorsal and ventral sides. Decoloration of the skin surrounding some of the ulcers was evident. This decoloration was absent on some fish but was pronounced on others

whitish, slightly elevated zone. Frequently, large irregular ulcers were situated at the base of the fins, on the operculum, or on the head, exposing the underlying bony tissue. Some ulcers were surrounded by a larger zone of marked decoloration of the skin. The number of lesions varied considerably from one fish to another, ranging from 1 to more than 20 per fish.

The ulcers as well as the kidneys from several specimens, collected on 2 occasions within a $1 \frac{1}{2}$ mo period, were examined bacteriologically. Pin-point, non-pigmented colonies were cultured from all specimens. The bacterium grew in very large numbers and in pure culture from the kidneys of all animals tested. However, Vibrio species were also cultured from the ulcers. The small colonies together with some Vibrio anguillarum like colonies were subcultured on blood agar to ensure that they represented pure cultures before studies to identify the cultures were undertaken.

The Vibrio anguillarum-like isolates proved to be $V$ anguillarum, strains representing 2 serotypes (O1 and $\mathrm{O} 2$ ) being identified.

The cultures derived from the small colonies were subjected to biochemical tests. Cells from $48 \mathrm{~h}$ brain heart infusion (BHI) broth (DifCo) cultures were short rods, $0.5 \times 1-3 \mu \mathrm{m}$. The bacteria were Gram-negative, non-motile, oxidase-negative, catalase-positive, and metabolized glucose by the fermentative pathway, and they were considered to belong to the genus Aeromonas (Popoff 1984) although they were oxidasenegative. Further characterization and comparisons with the type strains $A$. salmonicida subsp. salmonicida NCMB 1102 and A. salmonicida subsp. achromogenes NCMB 1110 were conducted as shown in Table 1 . As a result, the strains were identified as atypical A. salmonicida.

The bacteria showed a positive reaction in the slide agglutination test with rabbit antiserum raised against Aeromonas salmonicida subsp. salmonicida, and colonies were Coomassie blue- and Congo red-positive. In western blots, serum from infected turbot reacted with purified protein $\mathrm{A}$ and with an approximately $49 \mathrm{kDa}$ protein from the atypical $A$. salmonicida strain. These results suggested that the isolate produced a protein A-like compound.

The strains were sensitive to sulphonamides + trimethoprim (Tribrissen ${ }^{\circledR}$ ), oxolinic acid, nitrofurantoin, and tetracycline. They showed intermediate sensitivity to sulphonamides but were resistant to trimethoprim.

Onset and progression of the infection developed in parallel with a marked increase in the water temperature caused by a period of warm sunny weather (Fig. 3). Mortality increased in the farm for $5 \mathrm{wk}$, 
Table 1. Biochemical reactions of atypical Aeromonas salmonicida isolated from turbot Scophthalmus maximus, compared with A. salmonicida subsp. salmonicida NCMB 1102 and A. salmonicida subsp. achromogenes NCMB 1110 . + and - indicate positive and negative reactions, respectively, while $\mathrm{R}$ indicates resistance and S sensitivity to the test antibiotic

\begin{tabular}{|c|c|c|c|}
\hline Feature & $\begin{array}{l}\text { Strains from turbot } \\
\qquad(\mathrm{n}=5)\end{array}$ & $\begin{array}{l}\text { A. salmonicida subsp. } \\
\text { salmonicida NCMB } 1102\end{array}$ & $\begin{array}{l}\text { A. salmonicida subsp. } \\
\text { achromogenes NCMB } 1110\end{array}$ \\
\hline Cell morphology & Short rods & Short rods & Short rods \\
\hline Gram reaction & - & - & - \\
\hline Motility & - & - & - \\
\hline Oxidase & - & + & + \\
\hline Catalase & + & + & + \\
\hline Haemolysis & - & + & - \\
\hline Brown pigment & - & + & - \\
\hline Arginine dihydrolase & + & + & + \\
\hline Lysin decarboxylase & - & + & - \\
\hline Ornithin decarboxylase & - & - & - \\
\hline Indole & - & - & + \\
\hline Aesculin & + & + & - \\
\hline Voges-Proskauer & + & - & - \\
\hline Acid from glucose & + & + & + \\
\hline Gas from glucose & - & + & - \\
\hline \multicolumn{4}{|l|}{ Acid from: } \\
\hline d-Arabinose & - & - & - \\
\hline 1-Arabinose & - & + & - \\
\hline Salicin & + & + & - \\
\hline Sucrose & - & - & + \\
\hline Mannitol & - & + & + \\
\hline Trehalose & - & + & + \\
\hline Gelatine & + & + & + \\
\hline Penicillin, high, $62.5 \mu \mathrm{g}$ & $\mathrm{R}$ & $\mathrm{S}$ & $\mathrm{R}$ \\
\hline Cephalotin $66 \mu \mathrm{g}$ & $\mathrm{R}$ & $\mathrm{S}$ & $\mathrm{R}$ \\
\hline $\mathrm{O} / 129,150 \mu \mathrm{g}$ & $\mathrm{R}$ & $\mathrm{R}$ & $\mathrm{R}$ \\
\hline $0 / 129,10 \mu g$ & $\mathrm{R}$ & $\mathrm{R}$ & $\mathrm{R}$ \\
\hline Novobiocin, $5 \mu \mathrm{g}$ & $\mathrm{R}$ & $\mathrm{R}$ & $\mathrm{R}$ \\
\hline
\end{tabular}

whereafter treatment with sulphonamides + trimethoprim (Tribrissen ${ }^{(3)}$ was initiated and performed 3 times a week for $3 \mathrm{wk}$ (Fig. 3). After the antibacterial treatment, the mortality decreased significantly. However, the ulcers healed very slowly, leaving scars in the skin as well as in the muscle. A few weeks after this outbreak, mortality suddenly increased again dramati- cally. This time, a Vibrio anguillarum, serogroup O1, was isolated from all fish examined. The rainbow trout had been vaccinated against vibriosis and no vibriosis was recorded among them. The turbot, however, had not been vaccimated against vibriosis.

Due to the high mortality among the turbot during the 2 disease outbreaks and the poor quality of surviv-

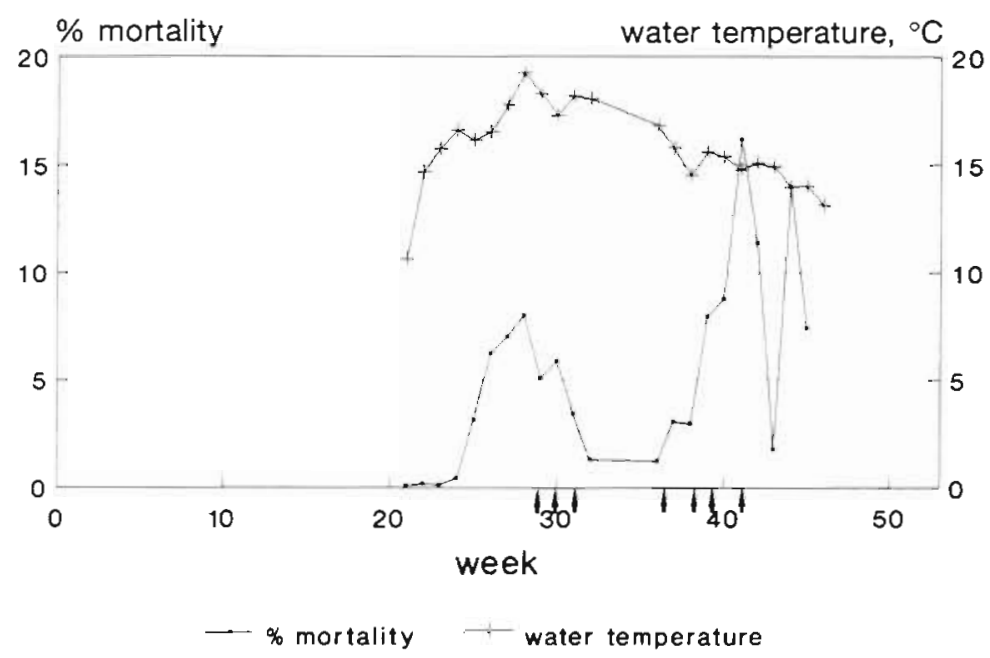

Fig. 3. Scophthalmus maximus. Water temperature and turbot mortality (as a percentage of surviving fish) was recorded during the outbreak. The first peak, Weeks 25 to 32 , was caused by the atypical Aeromonas salmonicida while the second peak, Weeks 37 to 45, was caused by Vibrio anguillarum serotype 01 Antibiotic treatment is indicated by arrows 
ing fish, the remaining turbot on the farm were destroyed.

The source of the atypical Aeromonas salmonicida infection is unknown. The bacterium did not appear to cause problems among the rainbow trout on the farm. However, because the fish farm had a large production of rainbow trout, it was decided to determine whether the turbot pathogen was also pathogenic to salmonids. However, in the $\mathrm{L}_{50}$ test with the rainbow trout no fish died during a 2 mo observation period. The challenged fish were therefore killed and examined bacteriologically. Swabs collected from the pronephros were inoculated onto BA plates and incubated at $20^{\circ} \mathrm{C}$. All specimens proved to be sterile. It was therefore concluded that the strain had no or very low pathogenicity for salmonids.

The epizootiology, clinical signs, and pathological changes observed in the present case were similar to those described by Devesa et al. (1989). However, these authors reported the finding of Cryptocarion spp., myxobacteria, and halophilic, urease-positive Vibrio strains in the lesions. No Aeromonas or Aeromonas - like microorganisms were reported. In the present, study the microorganisms found by Devesa et al. (1989) were not detected.

Reports on the existence of oxidase-negative forms of Aeromonas salmonicida are relatively new and therefore few in number. Chapman et al. (1991) described the isolation from coho salmon Oncorhynchus kisutch of an oxidase-negative bacterium that otherwise had the characteristics of $A$. salmonicida subsp. salmonicida. This was reported as the first isolation of an oxidase-negative $A$. salmonicida, and such strains were considered to be extremely rare. Almost simultaneously, Wiklund \& Bylund (1991) reported the isolation of an oxidase-negative presumptively atypical $A$. salmonicida from ulcers of flounders Platichthys flesus in the Baltic Sea. The present strain, isolated from turbot, is to our knowledge the first description of an oxidase-negative $A$. salmonicida from Denmark and from. turbot. The strain differed in various characters from the subspecies of A. salmonicida listed by Popoff (1984) and from the $A$. salmonicida subsp. smithia, proposed by Austin et al. (1989) and Austin (1993). However, its isolation should serve to alert fish health researchers to the existence of a hitherto unrecognized but potentially important group of fish pathogenic bacteria - a group that will require more study to answer questions on its taxonomy, ecology, epizootiology, and pathogenicity.

Acknowledgements. The technical assistance of Mrs Kirsten Kaas and the support of The Danish Agricultural and Veterinary Research Council grant no. 13-4710-1 and 134508-1 are gratefully acknowledged.

\section{LITERATURE CITED}

Austin, B. (1993). Recovery of 'atypical' isolates of Aeromonas salmonicida, which grow at $37^{\circ} \mathrm{C}$, from ulcerated nonsalmonids in England. J. Fish Dis. 16: 165-168

Austin, B., Austin, D. A. (1987). Bacterial fish pathogens: disease in farmed and wild fish. Ellis Horwood Ltd, Chichester, p. 111-171

Austin, D. A., Mclintosh, D., Austin, B. (1989). Taxonomy of fish associated Aeromonas spp., with the description of Aeromonas salmonicida subsp. smithia subsp. nov. Syst. appl. Microbiol. 11: 277-290

Chapman, P. F., Cipriano, R. C., Teska, J. D. (1991). Isolation and phenotypic characterization of an oxidase-negative Aeromonas salmonicida causing furunculosis in coho salmon (Oncorhynchus kisutch). J. Wildl. Dis. 27: 61-67

Cornick, J W., Morrison, C. M., Zwicker, B., Shum, G. (1984). Atypical Aeromonas salmonicida infection in Atlantic cod, Gadus morhua. J. Fish Dis. 7: 495-499

Cowan, S. T. (1974). Cowan and Steel's manual for the identification of medical bacteria. Cambridge University Press, Cambridge

Dalsgaard, I., Paulsen, H. (1986). Atypical Aeromonas salmonicida isolated from diseased sand-eels, Ammodytes lancea (Cuvier) and Hyperoplus lanceolatus (Lesauvage). J. Fish Dis. 9: 361-364

Devesa, S., Barja, J. L., Toranzo, A. E. (1989). Ulcerative skin and fin lesions in reared turbot Scophthalmus maximus (L.). J. Fish Dis. 12: 323-333

Elliott, D. G., Shotts, E. B. Jr (1980). Aetiology of an ulcerative disease in goldfish Carassius auratus (L.): microbiological examination of diseased fish from seven locations. J. Fish Dis. 3: 133-143

Evenberg, D., Versluis, R., Lugtenberg, B. (1985). Biochemical and immunological characterization of the cell surface of the fish pathogenic bacterium Aeromonas salmonicida. Biochim. biophys. Acta 81. 233-244

Håstein, T., Saltveit, S. J., Roberts, R. J. (1978). Mass mortality among minnows Phoxinus phoxinus (L.) in Lake Tveitevatn, Norway, due to an aberrant strain of Aeromonas salmonicida. J. Fish Dis. 1: 241-249

Ishiguro, E. E., Ainsworth, T., Kay, W. W., Trust, T. J. (1986). Heme requirement for growth of fastidious atypical strains of Aeromonas salmonicida. Appl. environ. Microbiol. 51 $668-670$

Ishiguro, E. E., Ainsworth, T., Trust, T J., Kay, W. W. (1985) Congo red agar, a differential medium for Aeromonas salmonicida, detects the presence of the cell surface protein array involved in virulence. J. Bacteriol. 164: $1233-1237$

Kitao, T., Yoshida, T., Aoki, T., Fukudome, M. (1985). Characterization of an atypical Aeromonas salmonicida strain causing epizootic ulcer disease in cultured eel. Fish Pathol. 20: 107-114

Kofod, H., Pedersen, K., Larsen, J. L., Buchmann, K. (1994). Purification and characterization of IgM-like immunoglobulin from turbot (Scophthalmus maximus L.). Acta vet. scand. (in press)

Laemmli, U. K. (1970). Clevage of structural proteins during the assembly of the head of bacteriophage T4. Nature 227: $680-685$

McCarthy, D. H. (1977). The identification and significance of atypical strains of Aeromonas salmonicida. Bull. off. Int. Epiz. 87: 459-463

Paterson, W.D., Douey, D., Desautels, D. (1980). Isolation and identification of an atypical Aeromonas salmonicida strain causing epizootic losses among Atlantic salmon (Salmo 
salar) reared in a Nova Scotian hatchery. Can. J. Fish. Aquat. Sci. 37: 2236-2241

Popoff, M. (1984). Genus III. Aeromonas. Kluyver and Van Niel 1936,398 In: Krieg, N. R., Holt, J. G. (eds,) Bergey's manual of systematic bacteriology, Vol. 1 Williams and Wilkins, Baltimore, p. 545-548

Reed, L. J., Muench, H. (1938). A simple method of estimating fifty per cent endpoints. Am. J. Hyg. 27: 493-497

Sorensen, U. B. S., Larsen, J. L. (1986) Serotyping of Vibrio anguillarum. Appl environ. Microbiol. 51: 593-597

Whittington, R. J., Gudkovs, N., Carrigan, M. J., Ashburn,

Responsible Subject Editor: T. Evelyn, Nanaimo, B.C., Canada
L. D., Thursten, S. J (1987). Clinical microbiological and epidemiological findings in recent outbreaks of goldfish ulcer disease due to atypical Aeromonas salmonicida in south-eastern Australia. J. Fish Dis. 10: 353-362

Wiklund, T. (1990). Atypical Aeromonas Salmonicida isolated from ulcers of pike, Esox lucius L. J. Fish Dis. 13: 541-544

Wiklund, T., Bylund, G. (1991). A cytochrome oxidase negative bacterium (presumptively an atypical Aeromonas salmonicida) isolated from ulcerated flounders (Platichthys flesus (L.)) in the northern Baltic Sea. Bull. Eur. Ass. Fish Pathol. $1174-76$

Manuscript first received: April 20, 1993

Revised version accepted: November 3,1993 